\title{
GAMBARAN HIGIENE DAN INFEKSI KECACINGAN PETUGAS PENGANGKUT SAMPAH DI KELURAHAN KEBRAON, KECAMATAN KARANGPILANG, SURABAYA
}

\author{
The Description Of Hygiene And Worm Infection Among Garbage Colectors In Kebraon \\ Village, Karangpilang District, Surabaya \\ Yenni Dwi Kurniawaty ${ }^{1}$, R. Azizah ${ }^{2}$ \\ Departemen Kesehatan Lingkungan Fakultas Kesehatan Masyarakat \\ Universitas Airlangga \\ yennidwikurniawaty@gmail.com
}

\begin{abstract}
Garbage collectors are at risk for worm infection due to working in risky environments. Worm infection is a disease caused by a parasite. This study was conducted to identify the conditions of hygiene and worm infection among garbage collectors in Kebraon Village, Karangpilang District, Surabaya. This research was conducted with a cross sectional study design. The sample size used in the study was 15 workers. Individual characteristics studied by researchers are working period, worker's age, the amount of income, ethnicity, and education level. The dominant age group of workers is 45-54 with a percentage of 40\%, 46.6\% of workers have been working for more than 20 years, 46.7\% of workers have an income of Rp 550.001-1.100.000 each month, all workers from East Java, and total 53.3\% of workers had a recent education at junior high school. Hygiene behavior that have been studied are use of personal protective equipment while working, the habit of washing hands with soap and clean water, the habit of cutting nails and bathing habits. The result of this study is all respondents have good hygiene behavior. In addition, scores on each variable of hygiene behaviors included in good category. Diagnosis of worm infection is performed by fecal sample laboratory examination. Fecal sample test results showed that 100\% of the garbage collectors did not have worm infection. The conclusion from this study is that workers have good hygiene behavior would not be affected by worm infection. Although garbage collectors are not affected worm infection and anemia, this situation should be maintained and improved in order not affected by other diseases due to work with garbage.
\end{abstract}

Keywords: Hygiene, worm infection, garbage collectors. 


\begin{abstract}
ABSTRAK
Petugas pengangkut sampah memiliki risiko terkena penyakit infeksi kecacingan karena bekerja di lingkungan yang berisiko. Infeksi kecacingan merupakan penyakit yang diakibatkan oleh parasit. Penelitian ini dilakukan untuk mengidentifikasi kondisi higiene dan infeksi kecacingan pada petugas pengangkut sampah di Kelurahan Kebraon, Kecamatan Karangpilang, Kota Surabaya. Penelitian ini dilakukan dengan rancangan studi cross sectional. Besar sampel yang digunakan sebanyak 15 orang. Karakteristik individu yang diteliti oleh peneliti adalah lama bekerja, usia pekerja, jumlah pendapatan, etnis, dan tingkat pendidikan. Kelompok umur pekerja yang dominan adalah 45-54 tahun sebanyak 40\%, sebanyak 46.6\% pekerja telah bekerja selama lebih dari 20 tahun, sebanyak $46.7 \%$ pekerja memiliki pendapatan yang didominasi sebesar Rp 550.001-1.100.000 tiap bulannya, seluruh pekerja berasal dari Jawa Timur, dan sebanyak 53.3\% pekerja memiliki pendidikan terakhir di tingkat sekolah menengah pertama. Perilaku higiene yang diteliti adalah pemakaian alat pelindung diri saat bekerja, kebiasaan mencuci tangan dengan air bersih dan sabun, kebiasaan memotong kuku, dan kebiasaan mandi. Hasil dari penelitian ini adalah seluruh petugas memiliki perilaku higiene yang baik. Selain itu, skor pada masing-masing variabel perilaku higiene termasuk dalam kategori baik. Diagnosis tetap infeksi kecacingan dilakukan dengan pemeriksaan laboratorium sampel tinja. Hasil pemeriksaan sampel tinja menunjukkan bahwa 100\% petugas pengangkut sampah tidak mengalami infeksi kecacingan. Kesimpulan dari penelitian ini adalah pekerja yang memiliki perilaku higiene yang baik tidak terkena infeksi kecacingan. Meskipun petugas pengangkut sampah tidak mengalami infeksi kecacingan, keadaan ini harus tetap dijaga dan ditingkatkan agar tidak terkena penyakit lain karena bekerja dengan sampah.
\end{abstract}

Kata kunci : Higiene, infeksi kecacingan, petugas pengangkut sampah.

\section{PENDAHULUAN}

Setiap mahkluk hidup memiliki kemampuan untuk berevolusi sebagai salah satu cara untuk dapat beradaptasi dengan lingkungannya. Hal ini juga terjadi pada manusia baik itu berupa evolusi secara fisik maupun akal/pikiran. Evolusi yang dialami akan membuat peradaban manusia semakin berkembang setiap tahunnya, baik secara sosial, ekonomi, industry, ilmu pengetahuan, teknolongi, dan sebagainya. Perkembangan atau pembangunan tersebut dapat memberikan dampak postif maupun negatif bagi makhluk hidup dan lingkungan sekitarnya, termasuk manusia sendiri. Salah satu dampak positif adanya pembangunan adalah mempermudah hidup manusia dan meningkatkan taraf hidup manusia. Sedangkan dampak negatif yang diakibatkan oleh pembangunan adalah lingkungan mengalami kerusakan fisik karena terjadi pencemaran air, udara, tanah maupun udara. Pencemaran fisik ini dapat berupa dari pembuangan sampah yang dilakukan seharihari oleh manusia untuk memenuhi kebutuhan hidupnya.
Menurut Silalahi (2010) sampah dalam ilmu kesehatan lingkungan sebenarnya hanya sebagian dari benda atau hal-hal yang dipandang tidak digunakan, tidak dipakai, tidak disenangi, atau harus dibuang, sedemikian rupa sehingga tidak sampai mengganggu kelangsungan hidup. Sedangkan menurut Undang-Undang No. 18 Tahun 2008, sampah adalah sisa kegiatan sehari-hari manusia dan/atau proses alam yang berbentuk padat. Saat ini, Indonesia memiliki jumlah penduduk sebanyak 237 juta dan diperkirakan menghasilkan sampah sebanyak 130.000 ton/hari (Kementrian Lingkungan Hidup, 2014). Ditinjau dari sudut ekologis, ada tiga faktor yang dapat menimbulkan suatu kesakitan, kecatatam, ketidakmampuan, atau kematian pada manusia. Tiga faktor itu disebut sebagai ecological atau epidemiologic triad yang terdiri atas agen penyakit, manusia, dan lingkungannya. Dalam keadaan normal, ketiga komponen tersebut atau dengan kata lain orang disebut sehat. Pada suatu saat keseimbangan dinamis tersebut terganggu, misalnya saat kualitas hidup menurun sampai tingkatan tertentu, agen penyakit dengan 
mudah masuk ke dalam tubuh manusia dan menimbulkan sakit (Chandra, 2007).

Berdasarkan konsep segitiga epidemiologi tersebut dapat diaplikasikan pada dampak buruknya sampah pada manusia. Sampah yang berada di lingkungan memberikan kesempatan pada agen penyakit untuk merugikan manusia yang ada disekitarnya. Agen penyakit yang berasal dari sampah adalah virus, bakteri, jamur, dan parasit. Agen penyakit tersebut dapat merugikan manusia dengan cara menyebarkan penyakit apabila kondisi sampah yang menumpuk, beberapa penyakit yang bisa disebabkan oleh sampah antara lain dermatitis, infeksi kecacingan, diare, kolera, dan sebagainya. Untuk mencegah terjadinya hal tersebut, dibutuhkan sistem pengelolaan sampah yang efisien dan efektif. Sistem pengelolaan sampah membutuhkan sumber daya manusia dalam prosesnya, sehingga muncul berbagai pekerjaan baru baik untuk masyarakat yang berpendidikan tinggi maupun rendah.

Kota Surabaya merupakan kota terbesar kedua di Indonesia setelah Jakarta yang terletak diantara $07^{0} 12^{\prime}-07^{0} 21^{\prime}$ Lintang Selatan dan $112^{0} 36^{\prime}-112^{0} 54^{\prime}$ Bujur Timur, dengan luas $333,063 \mathrm{~km}^{2}$ dan lautan seluas $190,39 \mathrm{~km}^{2}$. Wilayah Kota Surabaya dibagi menjadi 31 Kecamatan dan 163 Kelurahan. Berdasarkan dari data sensus penduduk tahun 2010 menyatakan bahwa Kota Surabaya memiliki jumlah penduduk mencapai 2.7 juta jiwa (BPS, 2010). Menurut prakiraan, setiap orang menghasilkan volume sampah sebanyak 0,5kg/kapita/hari (Sudrajat, 2006). Sehingga dengan jumlah penduduk 2.7 juta jiwa dapat diprakirakan bahwa Kota Surabaya menghasilkan sampah sebanyak 1.350 ton setiap harinya. Pengelolaan sampah di Surabaya merupakan tanggung jawab dari Dinas Kebersihan dan Pertamanan kota Surabaya. Sistem pengelolaan sampah di Surabaya sudah menerapkan konsep 3R (Reduce, Reuse, dan Recycle). Dalam proses pengelolaan sampah terdapat proses pengangkutan sampah yang akan memindahkan sampah dari rumah tangga menuju ke tempat penampungan sementara (TPS) yang kemudian akan berakhir di tempat pemrosesan akhir (TPA). Kota Surabaya memiliki satu unit TPA dan 164 unit TPS (BLH, 2011).

Kelurahan Kebraon, Kecamatan Karangpilang, Kota Surabaya terbagi menjadi 13 Rukun Warga (RW) dan 74 Rukun Tetangga (RT) dengan jumlah penduduk sebanyak 29.889 jiwa. Sistem pengelolaan sampah Kelurahan Kebraon berawal dari pengangkutan sampah tiap rumah tangga ke TPS Kelurahan Kebraon yang kemudian akan diangkut menuju TPA Kota Surabaya. Salah satu jenis pekerjaan yang muncul dari praktik sistem pengelolaan sampah adalah petugas pengangkut sampah. Banyak masyarakat yang berfikir bahwa sampah merupakan hal yang tidak berguna, akan tetapi untuk sebagian orang menganggap bahwah sampah merupakan sumber mata pencaharian mereka. Petugas pengangkut sampah yang dimaksud adalah orang yang memiliki tanggung jawab untuk memindahkan sampah dari rumah tangga menuju tempat penampungan sementara. Setiap pekerjaan memiliki berbagai risiko penyakit, tidak terkecuali petugas pengangkut sampah karena pekerjaannya mengaruskan untuk melakukan kontak langsung dengan sampah setiap harinya. Salah satu risiko penyakit yang dimiliki oleh petugas pengangkut sampah adalah infeksi kecacingan. Orang dewasa memiliki risiko terkena penyakit kecacingan, misalnya pada pekerja yang bersentuhan langsung dengan tanah (Siregar, 2013). Petugas pengangkut sampah juga merupakan pekerja yang banyak bersentuhan dengan tanah (Islami et al., 2014). Sehingga dalam praktiknya petugas pengangkut sampah harus melakukan beberapa upaya pencegahan agar tidak terkena penyakit infeksi kecacingan akibat sampah.

Penelitian yang dilakukan oleh Polaku (2014) yang mengindikasikan adanya risiko penyakit kecacingan pada pekerja pengangkut sampah di Kota Gorontalo. Beberapa penyebab adanya risiko infeksi kecacingan pada petugas adalah penggunaan alat pelindung diri, pengetahuan, dan sikap akan sampah dan infeksi kecacingan. Hal ini didukung dengan penelitian yang dilakukan oleh Islami et al pada tahun 2014 menyatakan bahwa penggunaan alat pelindung secara statistik memiliki hubungan dengan kejadian 
infeksi cacing pada petugas pengangkut sampah. Serta penelitan yang dilakukan oleh Ottay pada tahun 2010 menyatakan bahwa perilaku pemulung tentang pengetahuan dan sikap mempunyai hubungan dengan kejadian cacingan dan tindakan pemulung tidak mempunyai hubungan dengan kejadian cacingan di TPA Kota Manado.

Oleh karena itu, diperlukan kajian untuk melihat apakah pekerjaan sebagai petugas pengangkut sampah memiliki risiko terkena infeksi kecacingan sehingga dapat direncanakan upaya preventif atau promotifnya. Penelitian ini bertujuan untuk melihat kondisi higiene dan infeksi kecacingan petugas pengangkut sampah di Kelurahan Kebraon, Kecamatan Karangpilang, Kota Surabaya.

\section{METODE PENELITIAN}

Penelitian ini dilakukan di Kelurahan Kebraon, Kecamatan Karangpilang, Kota Surabaya. Penelitian ini merupakan penelitian observasional. Berdasarkan ruang lingkup tujuannya, penelitian ini termasuk penelitian deskriptif kuantitatif karena memperoleh data yang berbentuk angka yang kemudian akan diinterpretasikan. Sedangkain dari segi waktu, desain penelitian ini adalah cross sectional. Waktu penelitian dimulai pada bulan Desember 2015 hingga Juni 2016.

Populasi dalam penelitian ini adalah seluruh petugas pengangkut sampah di Kelurahan Kebraon. Dari 20 orang petugas yang bersedia untuk dijadikan sampel penelitian sebanyak 15 orang yang bekerja mengangkut sampah di beberapa RT setiap harinya. Identifikasi karakteristik individu dan perilaku higiene dilakukan dengan kuesioner dan observasi. Sedangkan identifikasi infeksi kecacingan dilakukan dengan pemeriksaan sampel tinja di laboratorium. Pengambilan sampel tinja dilakukan oleh responden dengan arahan dan pengawasan dari peneliti.

Penelitian ini telah memperoleh persetujuan dari Tim Komisi Etik Penelitian Kesehatan Fakultas Kesehatan Masyarakat Universitas Airlangga dengan nomor sertifikat kaji etik : 198-KEPK.

\section{HASIL PENELITIAN DAN PEMBAHASAN}

\section{Gambaran Umum Kelurahan Kebraon dan Petugas Pengangkut Sampah}

Kebraon merupakan sebuah kelurahan yang berada di wilayah Kecamatan Karangpilang, Kota Surabaya dan terbentuk pada tahun 1986 dengan luas wilayah sebesar 169.967 Ha. Kelurahan Kebraon memiliki 13 Rukun Warga (RW) dan 74 Rukun Tetangga (RT) dengan jumlah KK sebesar $8.383 \mathrm{KK}$ dengan jumlah penduduknya berjumlah 29.889 jiwa. Penduduk Kelurahan Kebraon memiliki mata pencaharian yang beragam yang didominasi oleh Pegawai Negeri Sipil (PNS), pegawai swasta, dan TNI/POLRI. Sedangkan untuk tingkat pendidikan yang dimiliki penduduknya beragam dan didominasi oleh tamat Sekolah Menengah Atas (SMA) yang kemudian diikuti dengan pencapaian tamat sekolah lanjutan Diploma atau Sarjana, sehingga tingkat pendidikan masyarakat Kelurahan Kebraon tergolong baik. Kelurahan Kebraon memiliki satu Tempat Penampungan Sementara (TPS) dan dilengkapi dengan gerobak yang berjumlah sesuai dengan jumlah RT yang dimiliki, yaitu 74 buah.

Menurut prakiraan, setiap orang menghasilkan volume sampah sebanyak 0,5kg/kapita/hari (Sudrajat, 2006). Dapat diprakirakan bahwa Kelurahan Kebraon menghasilkan sampah sebanyak 14.9445,5 $\mathrm{kg} / \mathrm{kapita} / \mathrm{hari}$ yang akan diangkut petugas menuju rumah tangga menuju TPS tiap harinya. Jumlah petugas pengangkut sampah yang bekerja di wilayah Kelurahan Kebraon sebanyak 20 orang. Menurut Peraturan Walikota Surabaya No. 42 tahun 2011 tentang Rincian Tugas dan Fungsi Dinas Kota Surabaya, Dinas Kebersihan dan Pertamanan Kota Surabaya memiliki kewenangan untuk pengangkutan sampah dari TPS ke TPA serta penyediaan sarana prasarana terkait. Hal tersebut mengakibatkan petugas pengangkut sampah di Kelurahan Kebraon dinaungi langsung oleh masing-masing RT, baik dari proses pembayaran, jumlah gaji, dan perekrutan yang mengakibatkan satu petugas dapat memiliki tanggung jawab untuk melakukan pengangkutan sampah pada dua 
sampai empat RT. Setiap harinya petugas pengangkut sampah akan mengambil sampah dari rumah tangga yang kemudian akan dimasukkan ke dalam truk sampah di TPS yang disediakan oleh Dinas Kebersihan dan Pertamanan (DKP). Proses pemindahan sampah dari gerobak menuju truk sampah dilakukan pada hari yang sama saat pengangkutan dari rumah tangga ke TPS. Sampah yang akan dipindahkan ke truk sampah akan dipilah terlebih dahulu, barangbarang yang dapat dijual kembali seperti kardus, botol plastik, maupun barang elektronik yang dapat digunakan kembali, sedangkan sampah yang lain akan dipindahkan ke truk sampah. Jam kerja petugas pengangkut sampah bervariasi tergantung pada keinginan setiap pekerja, beberapa pekerja menyukai pengangkutan pagi atau sore hari dan berdurasi sekitar 5-6 jam setiap harinya. Setiap tiga kali seminggu truk sampah dari.

\section{Karakteristik Individu Petugas Pengangkut Sampah}

Karakteristik individu yang diteliti dalam penelitian ini adalah usia, jenis kelamin, lama bekerja, pendapatan, etnis, dan tingkat pendidikan pada petugas pengangkut sampah yang didapatkan dari hasil kuesioner terhadap responden.

Usia pekerja dikelompokkan ke dalam kelompok umur 15-24 tahun, 25-34 tahun, 3544 tahun, 45-54 tahun, dan 55+ tahun sesuai dengan Peraturan Menteri Tenaga Kerja dan Transmigrasi Republik Indonesia Nomor 1 Tahun 2014 tentang Perubahan Atas Keputusan Menteri Tenaga Kerja dan Transmigrasi Nomor KEP. 250/MEN/XII/2008 Tentang Klasifikasi dan Karakteristik Data dari Jenis Informasi Ketenagakerjaan Menteri Tenaga Kerja dan Transmigrasi Republik Indonesia.

Variabel lama bekerja dikelompokkan menjadi 0 hingga 4, 5 hingga 9, 10 hingga 14, 15 hingga 19, dan lebih dari 20 tahun berdasarkan range menurut ilmu statistik yang dihitung menggunakan aplikasi statistik.

Untuk variabel pendapatan dibagi berdasarkan range dari data yang didapat yaitu Rp 0-550.000, Rp 550.001-1.100.000, Rp 1.100.001-1.650.000, dan Rp 1.650.001+.
Range variabel ini dihitung menggunakan aplikasi statistik.

Variabel etnis petugas pengangkut sampah dibagi berdasarkan hasil kuesioner yang didapat, apabila ditemukan tiga jenis etnis maka variabel ini akan dibagi tiga dan sebagainya.

Sedangkan untuk variabel tingkat pendidikan dibagi menjadi Sekolah Dasar (SD), Sekolah Menengah Pertama (SMP), dan Sekolah Menengah Atas (SMA) sesuai dengan sistem pendidikan yang ada di Indonesia.

Karakteristik individu petugas pengangkut sampah di Kelurahan Kebraon, Kecamatan Karangpilang, Kota Surabaya dapat dilihat pada tabel 1 .

Dari tabel tersebut dapat dilihat bahwa usia pekerja yang paling dominan adalah 20 tahun dengan presentase $40 \%$. Pada penyakit infeksi kecacingan tidak ada batasan usia, setiap orang bisa terkena apabila memiliki faktor risiko yang mendukung terjadinya penularan penyakit.

Sebagian bersar petugas pengangkut sampah memiliki lama kerja selama 20 tahun lebih sebanyak tujuh orang dengan presentase $46,6 \%$ yang selanjutnya diikuti oleh pekerja dengan lama kerja antara 10-14 tahun sebanyak empat orang dan 15-19 tahun serta 0-4 tahun dengan masing-masing jumlah sebanyak dua orang. Pada penelitian yang dilakukan oleh Siregar (2013) menghasilkan bahwa pekerja tanaman Kota Pekanbaru memiliki masa kerja lebih dari lima tahun pada 27 respondennya dengan presentase $100 \%$.

Jumlah pendapatan petugas pengangkut sampah didominasi pada kategori Rp 550.001 hingga Rp 1.100.000 sebanyak tujuh pekerja dengan presentase $46.7 \%$. Akan tetapi keseluruhan responden tidak memiliki pendapatan diatas Rp 2.000.000 yang sangat bertolak belakang dengan upah minimum regional (UMR) kota Surabaya sebesar Rp 3.045.000, padahal hal ini sangat berpengaruh terhadap pencukupan kebutuhan dasar setiap orang.

Tabel 1. Karakteristik Individu Petugas Pengangkut Sampah Kelurahan Kebraon, 
Kecamatan Karangpilang, Kota Surabaya, Mei 2016.

\begin{tabular}{|c|c|c|}
\hline \multirow{2}{*}{ Variabel } & \multicolumn{2}{|c|}{ Total } \\
\hline & $\mathbf{n}$ & $\%$ \\
\hline \multicolumn{3}{|l|}{$\begin{array}{l}\text { Usia pekerja } \\
\text { (tahun) }\end{array}$} \\
\hline $15-24$ & 0 & 0 \\
\hline $25-34$ & 2 & 13,3 \\
\hline $35-44$ & 5 & 33,3 \\
\hline $45-54$ & 6 & 40 \\
\hline $55+$ & 2 & 13,3 \\
\hline \multicolumn{3}{|l|}{ Lama } \\
\hline $\begin{array}{l}\text { bekerja } \\
\text { (tahun) }\end{array}$ & 2 & 13,3 \\
\hline $0-4$ & 0 & 0 \\
\hline $5-9$ & 4 & 28,5 \\
\hline $10-14$ & 2 & 13,3 \\
\hline $15-19$ & 7 & 46,6 \\
\hline \multicolumn{3}{|l|}{$20+$} \\
\hline \multicolumn{3}{|l|}{ Pendapatan } \\
\hline $\operatorname{Rp} 0-550.000$ & 0 & 0 \\
\hline $\begin{array}{l}\text { Rp 550.001- } \\
1.100 .000\end{array}$ & 7 & 46,7 \\
\hline $\mathrm{Rp}$ & 5 & 33,3 \\
\hline $1.100 .001-$ & & \\
\hline 1.650 .000 & 3 & 20 \\
\hline \multicolumn{3}{|l|}{$\mathrm{Rp}$} \\
\hline \multicolumn{3}{|l|}{$1.650 .000+$} \\
\hline \multicolumn{3}{|l|}{ Etnis } \\
\hline Jawa Timur & 15 & 100 \\
\hline \multicolumn{3}{|l|}{ Tingkat } \\
\hline Pendidikan & & \\
\hline SD & 5 & 33,3 \\
\hline SMP & 8 & 53,3 \\
\hline SMA & 2 & 13,4 \\
\hline
\end{tabular}

Berdasarkan data yang didapat bahwa seluruh petugas pengangkut sampah yang menjadi responden pada penelitian berasal dari wilayah yang sama yaitu Jawa Timur dengan presentase $100 \%$. Tingkat pendidikan pekerja didominasi oleh lulusan SMP sebanyak delapan orang dengan presentase $53,3 \%$, yang kemudian diikuti oleh lulusan SD sebanyak lima orang dengan presentase $33,3 \%$. Semakin rendah tingkat pendidikan seseorang akan memiliki risiko lebih tinggi untuk terkena infeksi kecacingan.

Perilaku Higiene Petugas Pengangkut Sampah
Perilaku higiene yang diteliti dalam penelitian ini adalah penggunaan alat pelindung diri, kebiasaan memotong kuku, kebiasaan mandi, dan kebiasaan mencuci tangan dengan air bersih dan sabun yang hasilnya didapat dari kuesioner dan observasi pada petugas pengangkut sampah. Perilaku higiene dilihat dari pengetahuan, sikap, dan tindakan responden dalam pelaksanaan keempat variabel diatas.

Berikut merupakan hasil pengukuran perilaku higiene petugas pengangkut sampah

Tabel 2. Higiene Petugas Pengangkut Sampah, Kelurahan Kebraon, Kecamatan Karangpilang, Mei 2016.

\begin{tabular}{lcc}
\hline \multirow{2}{*}{ Variabel } & \multicolumn{2}{c}{ Total } \\
\cline { 2 - 3 } & N & \% \\
\hline Penggunaan & & \\
APD & & \\
Baik & 15 & 100 \\
Buruk & 0 & 0 \\
\hline Kebiasaan & &
\end{tabular}

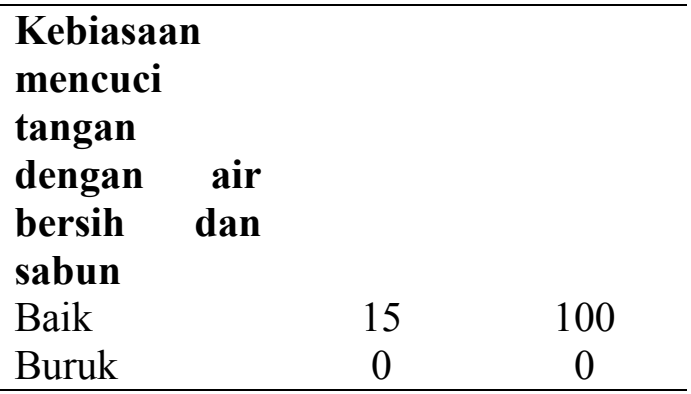

\begin{tabular}{lcc}
\hline $\begin{array}{l}\text { Kebiasaan } \\
\text { memotong } \\
\text { kuku }\end{array}$ & & \\
Baik & 15 & 100 \\
Buruk & 0 & 0 \\
\hline Kebiasaan & & \\
mandi & & \\
Baik & 15 & 100 \\
Buruk & 0 & 0 \\
\hline
\end{tabular}

\section{Perilaku}

\section{higiene}

$\begin{array}{lll}\text { Baik } & 15 & 100\end{array}$

\begin{tabular}{ccc} 
Buruk & 0 & 0 \\
\hline Personal & higiene & seluruh petugas
\end{tabular} pengangkut sampah termasuk dalam kategori baik $(100 \%)$ karena skor yang didapat berada diatas nilai rata-rata, seperti penelitian yang dilakukan oleh Polaku (2014) menyatakan dari 23 responden, sebanyak 14 orang $(60,9 \%)$ memiliki aspek higiene yang baik dan 
sebanyak 34,8\% atau delapan responden memiliki higiene yang cukup dan sebanyak $4,3 \%$ atau satu orang memiliki aspek higiene kurang.

Kondisi perilaku higiene seluruh petugas pengangkut sampah tergolong kategori baik, akan tetapi satu hal yang mencolok dari hasil penelitian adalah tindakan menggunakan alat pelindung diri terutama pemakaian sarung tangan. 15 pekerja tidak pernah menggunakan sarung tangan ketika bekerja, ketika ditanya kenapa alasan tidak menggunakannya mereka menjawab bahwa sudah terbiasa dan rasa tidak nyaman mengambil sampah apabila menggunakan sarung tangan. Untuk pemakaian sepatu boot ketika bekerja sebanyak 11 pekerja memakai sepatu boot sedangkan yang lainnya tidak menggunakannya. Berdasarkan penelitian yang dilakukan oleh Islami et al pada tahun 2014 menyatakan bahwa dari 59 sampel terdapat 14 sampel $(23.7 \%)$ yang menggunakan APD lengkap dan 45 sampel (76.3\%) tidak menggunakan APD lengkap pada petugas pengangkut sampah Dinas Kebersihan Kabupaten Wakatobi.

Kebiasaan mencuci tangan dengan air bersih dan sabun, kebiasaan mandi, dan kebiasaan memotong kuku pekerja termasuk pendingin. Penyimpanan sampel tinja tidak boleh lebih dari satu hari. Pengujian laboratorium sampel tinja digunakan untuk mengetahui apakah responden terkena penyakit infeksi kecacingan atau tidak. Hasil positif akan ditunjukkan dengan ditemukannya cacing atau telur cacing pada sampel tinja tersebut.

Berikut ini merupakan hasil laboratorium sampel tinja petugas pengangkut sampah :

Tabel 3. Infeksi Kecacingan Petugas Pengangkut Sampah, Kelurahan Kebraon, Kecamatan Karangpilang, Mei 2016.

\begin{tabular}{lcc}
\hline \multirow{2}{*}{ Variabel } & \multicolumn{2}{c}{ Total } \\
\cline { 2 - 3 } & n & \% \\
\hline Infeksi & & \\
Kecacingan & & \\
Negatif & 15 & 100 \\
Positif & 0 & 0 \\
& & \\
\hline
\end{tabular}

dalam kategori baik. Pada penelitian yang dilakukan oleh Polaku (2014) menghasilkan bahwa satu responden tidak memiliki kebiasaan memotong kuku, sementara 22 responden $(95.7 \%)$ pekerja lainnya memiliki kebiasaan memotong kuku setiap kali panjang pada petugas pengangkut sampah di Kota Gorontalo. Sedangkan pada penelitian Fitri et al (2012) menghasilkan bahwa kebiasaan cuci tangan siswa SD di Kecamatan Angkola Timur adalah 37\% siswa memiliki kategori baik dan 63\% siswa dalam kategori tidak baik. Sedangkan untuk penelitian yang dilakukan oleh Lengkong (2012) menghasilkan bahwa siswa SD Negeri 47 Kota Manado memiliki kebiasaan mandi yang baik sebanyak 95.5\% dan $4.5 \%$ memiliki kebiasaan mandi yang buruk.

\section{Infeksi Kecacingan Petugas Pengangkut Sampah}

Pengujian laboratorium sampel tinja dilakukan di Balai Besar Laboratorium Kesehatan Surabaya. Responden melakukan sampel tinja secara mandiri atas arahan dan pengawasan peneliti. Sampel tinja yang didapat harus ditutup rapat dan dimasukkan ke dalam kotak

Berdasarkan tabel diatas menyatakan bahwa seluruh petugas pengangkut sampah tidak memiliki penyakit infeksi kecacingam dengan presentase $100 \%$ karena tidak ditemukan telur cacing atau cacing dewasa pada sampel tinja mereka.

Infeksi kecacingan merupakan penyakit yang sering terjadi di masyarakat tetapi kurang mendapat perhatian dari berbagai sektor (neglected disease). Petugas pengangkut sampah memiliki risiko tertular penyakit karena bekerja pada lingkungan yang berisiko. Agen penyakit yang berasal dari sampah adalah virus, bakteri, jamur, dan parasit sehingga agen tersebut akan menghasilkan penyakit apabila sampah yang kita hasilkan menumpuk, antara lain dermatitis, infeksi kecacingan, penyakit diare, kolera, dan sebagainya. Pada penelitian Siregar (2013) menujukkan hasil pemeriksaan sampel yang dilakukan di laboratorium, maka 
didapatkan pekerja tanaman kota Pekanbaru yang mengalami infeksi kecacingan (positif) sebanyak 21 orang (77.78\%) dan tidak mengalami kejadian cacingan (negatif) sebanyak enam orang $(22.22 \%)$. Sedangkan menurut penelitian yang dilakukan Islami et al tahun 2014 mendapatkan hasil bahwa dari 59 sampel terdapat pada $31(52,5 \%)$ sampel yang terinfeksi dan terdapat $28(47,5 \%)$ sampel yang tidak terinfeksi pada petugas pengangkut sampah di Dinas Kebersihan Kabupaten Wakatobi.

Akan tetapi, penelitian yang dilakukan kali ini menghasilkan infeksi kecacingan negative karena pada pemeriksaan laboratorium tinja responden tidak ditemukan telur cacing atau cacing dewasa. Hal ini disebabkan karena personal higiene mereka tergolong baik meskipun tindakan penggunaan alat pelindung diri masih kurang terpenuhi.

Karakteristik Individu dan Perilaku Higiene dengan Infeksi Kecacingan pada Petugas Pengangkut Sampah

Identifikasi ini digunakan untuk melihat hubungan satu per satu variabel dengan infeksi kecacingan pada petugas

Tabel 4. Tabulasi Silang Antara Variabel Karakteristik Individu dan Perilaku Higiene dengan Infeksi Kecacingan pada Petugas Pengangkut Sampah.

\begin{tabular}{|c|c|c|c|c|c|c|}
\hline \multirow{3}{*}{ Variabel } & \multicolumn{4}{|c|}{ Infeksi Kecacingan } & \multicolumn{2}{|c|}{ Total } \\
\hline & \multicolumn{2}{|c|}{ Positif } & \multicolumn{2}{|c|}{ Negatif } & \multirow{2}{*}{$\mathbf{N}$} & \multirow{2}{*}{$\%$} \\
\hline & $\mathbf{N}$ & $\%$ & $\mathbf{N}$ & $\%$ & & \\
\hline \multicolumn{7}{|l|}{ Umur (tahun) } \\
\hline $15-24$ & 0 & 0 & 0 & 0 & 0 & 0 \\
\hline $25-34$ & 0 & 0 & 2 & 13,3 & 2 & 13,3 \\
\hline $35-44$ & 0 & 0 & 5 & 33,3 & 5 & 33,3 \\
\hline $45-54$ & 0 & 0 & 6 & 40 & 6 & 40 \\
\hline $55+$ & 0 & 0 & 2 & 13,3 & 2 & 13,3 \\
\hline \multicolumn{7}{|l|}{ Lama bekerja } \\
\hline $0-4$ & 0 & 0 & 0 & 0 & 0 & 0 \\
\hline $5-9$ & 0 & 0 & 4 & 28,5 & 4 & 28,5 \\
\hline $10-14$ & 0 & 0 & 2 & 13,3 & 2 & 13,3 \\
\hline $15-19$ & 0 & 0 & 7 & 46,6 & 7 & 46,6 \\
\hline \multicolumn{7}{|l|}{$20+$} \\
\hline \multicolumn{7}{|l|}{ Pendapatan } \\
\hline $\operatorname{Rp} 0-550.000$ & 0 & 0 & 0 & 0 & 0 & 0 \\
\hline Rp 550.001-1.100.000 & 0 & 0 & 7 & 46,7 & 7 & 46,7 \\
\hline & 0 & 0 & 5 & 33,3 & 5 & 33,3 \\
\hline
\end{tabular}




\begin{tabular}{|c|c|c|c|c|c|c|}
\hline $\begin{array}{l}\text { Rp 1.100.001- } \\
1.650 .000 \\
\operatorname{Rp} 1.650 .000+ \\
\end{array}$ & 0 & 0 & 3 & 20 & 3 & 20 \\
\hline \multicolumn{7}{|l|}{ Etnis } \\
\hline Jawa Timur & 0 & 0 & 15 & 100 & 15 & 100 \\
\hline \multicolumn{7}{|c|}{ Tingkat pendidikan } \\
\hline SD & 0 & 0 & 5 & 33,3 & 5 & 33,3 \\
\hline SMP & 0 & 0 & 8 & 53,3 & 8 & 53,3 \\
\hline SMA & 0 & 0 & 2 & 13,4 & 2 & 13,4 \\
\hline \multicolumn{7}{|c|}{ Penggunaan APD } \\
\hline Baik & 0 & 0 & 15 & 100 & 15 & 100 \\
\hline Buruk & 0 & 0 & 0 & 0 & 0 & 0 \\
\hline \multicolumn{7}{|c|}{$\begin{array}{l}\text { Kebiasaan mencuci } \\
\text { tangan dengan air } \\
\text { bersih dan sabun }\end{array}$} \\
\hline Baik & 0 & 0 & 15 & 100 & 15 & 100 \\
\hline Buruk & 0 & 0 & 0 & 0 & 0 & 0 \\
\hline \multicolumn{7}{|c|}{ Kebiasaan mandi } \\
\hline Baik & 0 & 0 & 15 & 100 & 15 & 100 \\
\hline Buruk & 0 & 0 & 0 & 0 & 0 & 0 \\
\hline \multicolumn{7}{|c|}{ Kebiasaan memotong } \\
\hline Baik & 0 & 0 & 15 & 100 & 15 & 100 \\
\hline Buruk & 0 & 0 & 0 & 0 & 0 & 0 \\
\hline \multicolumn{7}{|c|}{ Perilaku higiene } \\
\hline Baik & 0 & 0 & 15 & 100 & 15 & 100 \\
\hline Buruk & 0 & 0 & 0 & 0 & 0 & 0 \\
\hline
\end{tabular}

Perilaku higiene petugas pengangkut sampah Kelurahan Kebraon dikategorikan baik karena hasil skor kuesioner dan observasi yang melebih nilai rata-rata sehingga berdampak pada seluruh pekerja tidak terkena infeksi kecaingan, meskipun ada beberapa hal yang harus ditekankan terkait variabel pemakaian alat pelindung diri terutama sarung tangan. Pemakaian sarung tangan tidak dilakukan oleh seluruh petugas pengangkut sampah, sedangkan untuk penggunaan sepatu boot dilakukan oleh sebelas pekerja dan empat lainnya tidak menggunakannya. Beberapa hal yang menjadi faktor mengapa tidak menggunakan sarung tangan atau sepatu boot karena rasa tidak nyaman ketika mengambil sampah dan mereka telah terbiasa tidak menggunakannya. Hal ini bertolak belakang dengan penelitian yang dilakukan oleh Islami et al (2014) yang menghasilkan dari 45 sampel dari petugas pengangkut sampah yang tidak menggunakan APD secara lengkap, terdapat $27(60 \%)$ yang terinfeksi dan 18 (40\%) yang tidak terinfeksi. Hal ini terjadi karena variabel lain yang termasuk dalam perilaku higiene berkategori baik lebih mendominasi.

Perilaku higiene terkait variabel kebiasaan mandi, kebiasaan memotong kuku, dan kebiasaan mencuci tangan dengan air bersih dan sabun masuk dalam kategori baik. Hal ini sesuai dengan observasi peneliti yaitu ketika petugas pengangkut sampah bekerja selama lima hingga enam jam setiap hari, mereka tidak melakukan kegiatan selain bekerja seperti makan dengan menggunakan tangan secara langsung. Petugas pengangkut sampah akan langsung mencuci tangan dengan air bersih dari sumur terdekat dan menggunakan sabun sebelum pulang ke rumah masing-masing. Sesampainya di rumah mereka akan langsung mandi dan mengganti pakaian yang dipakai selama bekerja mengangkut sampah sebelumnya. Sesuai 
dengan penelitian yang telah dilakukan sebelumnya, apabila penelitian yang dilakukan oleh Ginting pada tahun 2009 pada anak SD di desa tertinggal Kecamatan Panguruan Kabupaten Samosir menghasilkan kejadian infeksi kecacingan pada siswa dengan personal higiene yang baik ialah 35\% dengan infeksi kecacingan positif dan $65 \%$ dengan infeksi kecacingan negatif. Kemudian untuk kejadian infeksi kecacingan pada siswa dengan personal higiene sedang ialah 51,4\% dengan indeksi kecacingan positif sedangkan untuk infeksi kecacingan negatif sebesar $48,6 \%$. Selanjutnya untuk kejadian indeksi kecacingan pada siswa dengan personal higiene buruk ialah $81,8 \%$ dengan infeksi kecacingan positif dan 18,2\% dengan infeksi kecacingan negatif. Semakin rendah personal higiene siswa, semakin tinggi pula kejadian infeksi kecacinggannya sehingga dapat disimpulkan ada ada hubungan bermakna antara buruknya personal higiene dengan kejadian kecacingan pada siswa SD di Kabupaten Samosir maka apabila kondisi personal higiene baik maka risiko untuk tertular infeksi kecacingan juga akan menurun.

Kebiasaan mencuci tangan yang buruk dapat memindahkan bibit penyakit ke dalam tubuh (Purwanijayanti, 2006). Pencucian tangan dengan sabun dan diikuti dengan pembilasan akan menghilangkan banyak mikroba yang terdapat pada tangan. Kombinasi antara aktivitas sabun sebagai pembersih, penggosokan dan aliran air akan menghanyutkan partikel kotoran yang banyak mengandung mikroba (Purnawijayanti, 2006). Sejalan dengan penelitian yang dilakukan oleh Siregar (2013) menyatakan bahwa ada hubungan antara kebiasaan mencuci tangan dengan sabun antiseptik dengan kejadian cacingan yaitu pada pekerja tanaman dengan kebiasaan mencuci tangan menggunakan sabun antiseptik yang kurang dengan menderita kejadian cacingan positif sebanyak 18 orang $(90 \%)$ dan kejadian cacingan pada pekerja tanaman kota dengan kebiasaan mencuci tangan dengan sabun antiseptik dengan cukup dan baik sebanyak tiga orang $(42,9 \%)$. Pernyataan tersebut disesuaikan dengan hasil skor kebiasaan mencuci tangan dengan air bersih dan sabun yang dikategorikan baik, maka risiko terkena infeksi kecacingan akan menurun.

Menurut penelitian yang dilakukan oleh Lengkong (2012) pada pelajar di SD Negeri 47 Kota Manado menghasilkan bahwa dari 64 pelajar yang memiliki kebersihan kuku tidak baik terdapat dua pelajar yang terkena infeksi kecacingan sedangkan dari 47 pelajar yang memiliki kebersihan kuku baik terdapat tiga pelajar yang terkena infeksi kecacingan. Sehingga diperoleh bahwa tidak ada hubungan antara kebersihan kuku dengan infeksi kecacingan. Dengan kondisi kebiasaan mandi, kebiasaan mencuci tangan dengan air bersih dan sabun, serta kebiasaan memotong kuku yang baik, sehingga risiko untuk terkena infeksi kecacingan juga semakin rendah karena beberapa aspek personal higiene masih terpenuhi.

\section{SIMPULAN DAN SARAN}

Dari penelitian ini dapat disimpulkan bahwa karakteristik individu petugas pengangkut sampah terdiri dari beberapa variabel, antara lain: umur pekerja didominasi oleh usia 45 hingga 54 tahun dengan presentase $40 \%$, sebanyak $46,6 \%$ pekerja memiliki masa kerja lebih dari 20 tahun, seluruh pekerja berasal dari Jawa Timur, tingkat pendidikan pekerja didomanis oleh lulusan SMP dengan presentase 53,3\%, dan sebagian besar pekerja mendapatkan jumlah pendapatan antara Rp 550.001 hingga Rp 1.100.000 setiap bulannya.

Perilaku higiene yang diteliti terdiri dari penggunaan alat pelindung diri, kebiasaan memotong kuku, kebiasaan mandi, dan kebiasaan mencuci tangan dengan air bersih dan sabun yang memiliki hasil bahwa skor perilaku higiene setiap variabel atau setelah diakumulasikan dari seluruh petugas pengangkut sampah termasuk dalam kategori baik karena skor yang didapat berada diatas rata-rata skor total.Sedangkan untuk hasil uji laboratorium pemeriksaan sampel tinja petugas pengangkut sampah mendapatkan hasil bahwa tidak ada pekerja yang menderita infeksi kecacingan.

Dalam penelitian ini, karakteristik individu dan perilaku higiene tidak memiliki hubungan dengan infeksi kecacingan. Hal ini dikarenakan pengaruh perilaku higiene yang 
termasuk dalam kategori baik pada seluruh petugas pengangkut sampah lebih dominan yang dapat mencegah terjadinya penularan infeksi kecacingan pada pekerja.

Saran untuk pekerja ialah petugas pengangkut sampah yang tidak lulus SD dan SMP bisa diarahkan untuk mengikuti ujian paket $\mathrm{A}$, B, dan $\mathrm{C}$ agar memiliki tingkat pendidikan yang lebih baik sehingga mampu meningkatkan kesejahteraan hidupnya dan dilakukan pengarahan terhadap pekerja untuk meningkatkan kesejahteraan hidupnya dari segi sosial ekonomi dengan cara bekerja selain sebagai petugas pengangkut sampah karena semakin tua usia seseorang maka kemampuan untuk mengangkut sampah semakin berkurang dan paparan penyakit yang diterima sudah terlalu lama sehingga sangat berisiko untuk terkena penyakit.

\section{DAFTAR PUSTAKA}

Badan Lingkungan Hidup Kota Surabaya. 2011. Laporan Status Lingkungan Hidup Daerah Kota Surabaya Tahun 2011. Diakses dari http://lh.surabaya.go.id/SLHD\%202 011/Laporan\%20BAB\%20I\%20Mat riks.pdf

Badan Pusat Statistik. 2010. Jumlah dan Distribusi Penduduk. Diakses dari http://sp2010.bps.go.id/index.php/sit $e ? d=3578000000 \&$ wilayah $=$ KotaSurabaya

Chandra, B. 2007. Pengantar Kesehatan Lingkungan. Jakarta: Penerbit Buku EGC

Fitri. J, Saam. Z, Hamidy. M.Y. 2012 Analisis Faktor-Faktor Risiko Infeksi Kecacingan Murid Sekolah Dasar di Kecamatan Angkola Timur Kabupaten Tapanuli Selatan Tahun 2012. Jurnal Ilmu Lingkungan Vol. 6 No. 2: 146-161. Diakses dari download.portalgaruda.org/article.p hp? article $=31889 \& v a l=227$

Ginting, A. 2009. Faktor-Faktor yang Berhubungan Dengan Kejadian Kecacingan pada Anak Sekolah Dasar di Desa Tertinggal Kecamatan Pangururan Kabupaten Samosir
Tahun 2008. Skripsi. Universitas Sumatera Utara: Medan. Diakses dari

repository.usu.ac.id/bitstream/12345 6789/14707/1/09E00823.pdf

Islami, L.N., Sulastrianah, dan Waode, S.A.U., 2014. Perbedaan Kejadian Infeksi Antara Petugas Pengangkut Sampah yang Menggunakan Alat Pelindung Diri dengan Petugas Sampah yang Tidak Menggunakan Alat Pelindung Diri. Medula Vol. 2 No. 1: 108-111. Diakses dari ojs.uho.ac.id/index.php/medula/artic le/download/242/182

Kementerian Lingkungan Hidup. R.I. 2014. Hari Peduli Sampah 2014: Deklarasi Indonesia Bersih Sampah 2020. Diakses dari http://www.menlh.go.id/hari-pedulisampah-2014-indonesia-bersih2020/

Lengkong. B.R., Joseph. W.B.S, Pijoh. V.D. Hubungan Antara Higiene Perorangan dengan Infestasi Cacing pada Pelajar Sekolah Dasar Negeri 47 Kota Manado. Jurnal Kesmas Vol 1, No 1: 28-35. Diakses dari http://fkm.unsrat.ac.id/wpcontent/uploads/2013/08/JurnalBrian-R.-Lengkong-091511146KESLING.pdf

Ottay, R.I., 2010. Hubungan Antara Perilaku Pemulung dengan Kejadian Penyakit Cacingan di Tempat Pembuangan Akhir Sampah Sumompo Kota Manado. Jurnal Biomedik, Vol. 2, No. 1: 38-43. Diakses dari http://ejournal.unsrat.ac.id/index.ph p/biomedik/article/view/841/659

Peraturan Menteri Tenaga Kerja dan Transmigrasi Republik Indonesia Nomor 1 Tahun 2014 tentang Perubahan Atas Keputusan Menteri Tenaga Kerja dan Transmigrasi Nomor KEP. 250/MEN/XII/2008 Tentang Klasifikasi dan Karakteristik Data dari Jenis Informasi Ketenagakerjaan Menteri Tenaga Kerja dan Transmigrasi Republik Indonesia 
Peraturan Walikota Surabaya No. 42 tahun 2011 tentang Rincian Tugas dan Fungsi Dinas Kota Surabaya, Dinas Kebersihan dan Pertamanan Kota Surabaya

Polaku, N. 2014. Identifikasi Telur Cacing pada Kuku dan Higiene Pekerja Pengangkut Sampah di Kota Gorontalo. Skripsi. Universitas Negeri Gorontalo: Gorontalo. Diakses dari eprints.ung.ac.id/7576

Purnawijayanti, Hiasinta, A., 2006. Sanitasi, Higiene, dan Keselamatan Kerja dalam Pengolahan Makanan. Yogyakarta: Penerbit Kanisius.

Silalahi, D.K. 2010. Hubungan Kebersihan Perorangan Dan Pemakaian Alat Pelindung Diri Dengan Keluhan Gangguan Kulit Pada Petugas Pengelola Sampah Di Tempat Pembuangan Akhir (TPA) Namo Bintang Kecamatan Pancur Batu Kabupaten Deli Serdang Tahun 2010. Skripsi. Universitas Sumatera Utara: Medan. Diakses dari http://repository.usu.ac.id/handle/12 $3456789 / 20777$

Siregar, I. 2013. Hubungan Personal Higiene dengan Penyakit Cacing (Soil Transmitted Helminth) pada Pekerja Tamanan Kota Pekanbaru. Pusat Penelitian Lingkungan Hidup Universitas Riau: 93-102. Diakses dari ejournal.unri.ac.id/index.php/JKL/ar ticle/view/1281

Sudrajat, H.R. 2006. Mengelola Sampah Kota. Jakarta: Penebar Swadaya Undang-Undang Republik Indonesia Nomor 18 Tahun 2008 Tentang Pengelolaan Sampah 